Teye, V., Turk, E.S., and S. Sönmez (2011). Heritage Tourism in Africa: Residents'

Perceptions of African-American and White Tourists. Tourism Analysis, 16(2):169-185.

Made available courtesy of Cognizant Communication Corporation:

https://www.cognizantcommunication.com/journal-titles/tourism-analysis

** Reprinted with permission. No further reproduction is authorized without written permission from Cognizant Communication Corporation.***

\title{
HERITAGE TOURISM IN AFRICA: RESIDENTS’ PERCEPTIONS OF AFRICAN-AMERICAN AND WHITE TOURISTS
}

\section{VICTOR TEYE,* ERCAN (SIRAKAYA) TURK,† and SEVIL SÖNMEZ}

*Business School, Ghana Institute of Management and Public Administration (GIMPA), Accra, Ghana $\dagger$ School of Hotel, Restaurant, and Tourism Management, University of South Carolina, Columbia, SC, USA

$\ddagger$ Recreation, Tourism, and Hospitality Management, University of North Carolina at Greensboro, Greensboro, NC, USA

\begin{abstract}
The growing interest in heritage tourism in Africa is reflected in the Cairo Declaration of 1995, which was adopted under the auspices of the World Tourism Organization (UNWTO) and the United Nations Educational, Scientific and Cultural Organization (UNESCO). The objective was for African countries to identify, develop, and preserve a number of World Heritage Sites in cooperation with international agencies and special interest groups. Ultimately, it was expected that such development would enhance the promotion of cultural, thus heritage and ethnic tourism as part of the continent's economic development strategy. A number of forts and castles built by Europeans are currently being restored for heritage tourism in Ghana and the country also has several vital cultural resource sites that are critical components of the "Slave Route Project." Cape Coast and Elmina are two communities in Ghana currently receiving an increasing number of international visitors, including a significant number of African-Americans to the three World Heritage Sites located in the two towns. The purpose of the article is to examine how residents of Cape Coast and Elmina perceive African-American and White tourists. Data for the study were gathered in Cape Coast and Elmina through interviewer-administered surveys. Results indicate significant differences in residents' perceptions of Black and White visitors. The study concludes that considerable care must be exercised in the development and utilization of historically sensitive areas and properties for tourism.
\end{abstract}

Key words: Residents' perceptions; Heritage tourism; African-Americans; Diaspora

Introduction

A common feature of contemporary social and economic life is the enormous volume of spatial movement of people, including a significant proportion of tourists visiting countries or regions that they consider as their ancestral home. This has resulted in the emergence of what can be referred to as "roots tourism" or "pilgrimage tourism," which is regarded as a subfield of ethnic or heritage tourism. Related to this domain, a majority of research in the social sciences that is commonly referred to 
as Diaspora Studies has been carried out in Sociology and Anthropology. However, it has been observed that "the literature on Diaspora (and hybridity) has, on the whole, neglected tourism, perhaps because tourists are thought to be temporary and superficial" (Bruner, 1996, p. 290). An emerging theme in tourism development in Africa is the incorporation of historical and cultural resources into the tourism product that is primarily directed to the African-American market in the US, as well as all Africans elsewhere in the Diaspora, especially those in the Caribbean, Latin America, and Europe. This article compares residents' perceptions and attitudes towards Black and White tourists visiting two communities in Ghana where heritage tourism is being developed with the objective of restoring historical and cultural resources and attracting Africans in the Diaspora. Prior to becoming independent in 1957, the country was known as the Gold Coast, a British colony that was one of the principal origins of slaves that were shipped to the Americas. Current heritage tourism development is directed at African heritage attributes, as well as those of various European countries, including the British, Dutch, Danish, and Portuguese. The objective of this article is therefore to examine how residents of Ghana perceive these two main groups of visitors who are attracted by their own heritage in this part of Africa.

This article is divided into five parts, beginning with a review of the literature on residents' perceptions of visitors, and heritage/ethnicity tourism. The second part of the article places the focal point of the study within the context of the Black Diaspora with a broad examination of the TransAtlantic Slave Trade. The third part of the article examines recent efforts to develop ethnic tourism in Ghana with the objective of attracting Africans in the Diaspora, especially African-Americans. This section also discusses the significance of the African-American market to tourism development in Ghana, and in Africa in general. Part four of the article presents the findings of the study on residents' comparative perceptions of AfricanAmericans and White visitors to Ghana. The final section of the article is a discussion of the research and its theoretical and practical implications.

\section{Background on Residents' Perceptions}

There is a substantial body of literature examining local residents' attitudes and perceptions toward tourists and the tourism industry in general. One reason for this interest is that "the perceptions and attitudes of residents toward tourism are likely to be important planning and policy considerations to successful development, marketing, and operation of existing and future tourism programs and projects" (Ap, 1992, p. 665). Unfortunately, hardly any work has been devoted to examining residents' attitudes toward the tourism industry and tourists in developing countries, especially in the inception stages of tourism development when the support and involvement of the local community is critical to the success of development efforts. Factors that have been shown to influence residents' perceptions and attitudes include the type and extent of host-guest (resident-visitor) interaction, length of residency in the community, the extent of tourism concentration in the community, importance of the industry to the general community, distance of residence from the central tourist zone, as well as different community constituents, extent of individuals' reliance on the tourism industry, and the overall level of tourism development in the community (Belislie \& Hoy, 1980; Canan \& Hennessey, 1989; Lui \& Var, 1986; Madrigal, 1993; Murphy, 1985; Pizam, 1978; Um \& Crompton, 1987). Other factors include historical relationships and experiences, and geographical setting of the community. For example, different colonial experiences are likely to result in different contemporary perceptions and attitudes toward visitors. These various colonial experiences may derive from, for example, the direct rule or assimilation model (French West Africa), indirect rule through local chiefs (British West African model), or the European settlement model (East, Central, and Southern Africa). With respect to the geographical setting of the destination, residents' perceptions and attitudes would vary between the urban-gateway-modern center and the rural-traditional periphery. Beyond these general factors, the influence of several specific factors on the nature and extent of residents' perceptions and attitudes toward tourism development have been identified. Some of the specific factors include: 
native-born status in the community (Canan \& Hennessey, 1989; Um \& Crompton, 1987), length of residency in the community (Liu \& Var, 1986), the extent of tourism concentration in the community (Pizam, 1978), economic reliance on the tourism industry (Madrigal, 1993), and distance of one's residence from the central tourist zone (Belisle \& Hoy, 1980).

A recent study on residents' perceptions of tourism development in Ghana found some degree of resentment toward the tourism industry due to a number of reasons. These included high expectations from tourism that had not been met for more than a decade, absence of community awareness, and involvement in the planning and development processes. Part of this latter problem was traced to the external nature of tourism project funding and implementation. What is not clear from these earlier studies is how perceptions and attitudes differ when two ethnically different groups interact with residents. Social exchange theory stipulates that benefits and costs are evaluated ubiquitous across a broad spectrum of tourists. However, tourism in Ghana is based on the regional West African market, Ghanaians living abroad visiting friends and relatives, Blacks in the African Diaspora on heritage visits, and white Caucasian visitors. Hence, residents' attitudes cannot be studied within a monolithic framework, where all tourists are treated the same. Thus, this study contributes to the literature in two important ways. First, it differentiates two groups of tourists: one that is ethnically related to the residents and the other ethnically different but historically connected through the slave trade and slavery. The second contribution of the study lies in its attempt to understand how residents' perceptions are formed using a select group of variables within the framework of the social exchange theory in a destination that is relatively in its inception state of tourism development.

\section{Heritage Tourism}

A large and diverse body of literature on the social and cultural dimensions of tourism has emerged over the last three decades. From a sociocultural perspective, tourism is viewed as a largescale phenomenon that brings people with diverse backgrounds into close proximity and contact. In practice, tourism can reinforce the reality of the global village and facilitate national and international contacts, while fostering interactions among "hosts" and "guests" (Smith, 1977). Political, cultural, and economic boundaries separating societies in the so-called First, Second, and Third World countries are regularly being crossed by tourists regardless of their race, gender, and religion. In the 1980 s, tourism studies began to examine an array of social and cultural issues (Brown \& Jafari, 1990) deriving from this large international movement, including heritage tourism, sometimes referred to as ethnic tourism (Adams, 1984; Esman, 1984; MacCannell, 1973).

Since the early 1980 s, tourism scholars have focused on the interrelationships between tourism and the array of diverse social and cultural issues (Brown \& Jafari, 1990). In this context, a substantial amount of work has appeared in the area of ethnic tourism. Hitchcock (1999) rightly pointed out that "Ethnicity permeates many aspects of tourism, but remains poorly understood in this context. Ethnicity is also a problematic concept because of its variability and the complexity of its interrelation with social structure" (p. 17). Following a fairly extensive review of the literature, Moscardo and Pearce (1999) summarized ethnic tourism as travel for the purpose of observing the cultural expressions and lifestyles of exotic people (McIntosh \& Goeldner, 1995); pursuing the unique or quaint customs of indigenous populations (Smith, 1977, 1989); and seeking ethnically exotic but authentic experiences in remote, untouched, pristine, and somewhat primitive destinations (van den Berghe, 1994). Within this context, according to Hitchcock (1999), destination activities that attract visitors include viewing or visiting homes in natives' villages, as well as watching dances and ceremonies (Smith, 1989). While some commentators have sought to expand the scope of ethnic tourism to include major ethnic groupings (Pitchford, 1995), the majority of studies fall within the definition of ethnic tourism in small and remote communities as "involving first hand experiences with the practices of another culture" (Harron \& Weiler 1992 , p. 84). Included in this grouping are the Amish of the US; Natives or "First Nation Societies" of North America in Canada, US, and Mexico; the Maori of New Zealand; Aboriginal groups 
in Australia; the bushmen of Southern Africa; and the Ibo tribes of Indonesia (Moscardo \& Pearce, 1999).

One relevant point must be highlighted from the review of what constitutes ethnic tourism. The definition appears to be limited to ethnic groups that are economically marginalized, and politically disenfranchised. The very existence of some, if not most, of these ethnic groups is threatened and has compelled some of them to resort to one form of cultural tourism or another. This conclusion is derived from the definition of ethnic tourism that "includes traditional and contemporary cultural presentations and performances, thus embracing those which are only partially for tourists as well as those which are wholly for visitors" (Moscardo \& Pierce, 1999, p. 417). Related to this observation is the use in the literature of such descriptive phrases as "quaint customs of indigenous peoples" and "shopping for primitive wares and curios" (Smith, 1977, 1989). Not surprisingly, a large body of work in the area of ethnic tourism has concentrated on the debate about the authenticity of tourist destinations, attractions, performances, and products. Fostered originally by the works of MacCannell (1973), the concept has been extended by others, including Cohen (1979, 1988), Hughes (1995), Crang (1996), and Daniel (1996).

Placing the discussion in a broad geographical context, Walle (1996) points out that the understanding of how tourists perceive ethnic experiences in developing countries and rural regions in developed countries is critically linked to these regions' desire to promote indigenous cultures in order to reap economic benefits. Obviously, ethnic tourists are not homogenous, and as such a number of commentators have devoted attention to ethnic market segmentation studies. For example, Hughes (1995) has made the distinction between two possible ethnic market segments. The first group, referred to, as the "postindustrial segment" is more likely to be sensitive to the impacts of its activities on the local population. More importantly, it is argued that this group is likely to behave more responsibly in the context of ethnic contacts. In other words, this group comes close to fitting models that advance sustainable tourism practices. The second group, labeled "the postmodern segment," is more likely to enjoy staged or contrived performances despite full awareness of their lack of authenticity. Allegedly, this group is characterized by active and flexible traits that allow it to embrace and enjoy diverse cultural tourism offerings. While examining the issue of authenticity with particular reference to marketing ethnic tourism in Third World countries, Silver (1993) referred to the emergence of another market segment of tourists. This group is considered to be well educated, sophisticated, and desirous of being morally responsible and politically correct.

This brief discussion on the definition of ethnic tourism, motivations for ethnic travelers, and the outcomes of their contacts with host populations, as well as the segmentation of ethnic tourism markets provides an important context for this study. The focus of this present study, however, falls within the domain of ethnic tourism studies that examine tourists whose primary reason is to visit their ancestral homes abroad. Because a significant proportion of international tourists traveling for a broad and diverse array of leisure purposes is motivated by such cultural reasons, tourists' ethnicity, and the impact of cultural identity upon their vacation preferences is becoming fairly well established in the tourism literature. A number of studies have examined motivations for travel to ancestral places of origin, while others have come to perceive such travel activities as forms of pilgrimage (Thanopoulos \& Walle, 1988). Crompton (1979), for example, sees "explanation and valuation of self" and enhancement of kinship relationships to be possible motives for taking vacations. The behavior of ethnics returning to ancestral homes is only one of several dimensions of the evolving concept of "pilgrimage tourism," which in recent years has been broadly interpreted to include both secular and sacred activities. Cohen (1988), for example, asserts that pilgrimage no longer needs to be religious in nature and suggests a generalized paradigm with the affirmation that "the pilgrim journeys to the Center which embodies the essential fact of his own culture" (Morinis, 1983, p. 570). Esman (1984) viewed Cajuns as a disenfranchised ethnic group using tourism to assert their heritage, and concluded that other ethnic groups that may have to travel extensively to return to the "old country" may be engaging in similar pilgrimage aimed at reasserting, reaffirming, or 
perpetuating their heritage. Taking this a step further, Thanopoulos and Walle (1988) viewed GreekAmericans as an American ethnic group living far away from their cultural and geographical origins. The authors examined the motives and propensity of this group to travel to Greece, and concluded that "ethnics who return home tends to do so periodically, not just once" (Thanopoulos \& Walle, 1988, p. 14).

While a few commentaries have appeared on ethnic tourism in Africa, including those by Jamison (1999), Africa has not often been linked with African-Americans as a distinct travel market segment. Goodrich (1985) in an exploratory study found that "outside the United States, a significant proportion $(71 \%)$ of respondents in that study indicated that they were most likely to visit a number of African countries" (p. 28). There are no statistics on the number of African-Americans traveling to Africa; however, because this study was conducted almost 20 years ago, the number of African Americans traveling to Africa has seen significant increase according to the travel trade organization, the Africa Travel Association (ATA, 1999). From a marketing standpoint alone, the 34 million African-Americans living in the US constitute a significant market for African countries. Because very little research has been conducted on this population group, it becomes even more important to understand factors such as AfricanAmericans' travel motivations, expectations, preferences, interaction with their hosts, as well as the issues of authenticity of their experiences. In the context of pilgrimage travel to one's ultimate place of origin, it has been noted that "such travel is risky for a number of reasons. For example, not only is foreign travel expensive but travel to an ancestral homeland may involve significant emotional trauma as well as opportunities" (Thanopoulos \& Walle, 1988, p. 12). In particular, travel from the US to Africa can be expensive. Two US carriers (Delta and United) and a few African airlines fly directly from the US to Ghana; however, their schedules are limited and the flights are often oversold. The more reliable flights on predominantly European carriers such as British Airways, KLM, and Lufthansa via their major hubs in London, Amsterdam, and Frankfurt tend to cost a lot more. Furthermore, travel to Africa is also per- ceived to be risky for health, safety, and security reasons. For African-Americans, however, going to Africa is more than a trip, a visit, or a tour. It is a journey that is in several ways unique to only the Black race. The experiences are individualistic but they consist of a mixture of the emotional and spiritual, educational and discovery, anxiety and apprehension, homecoming and cultural identity, as well as opportunities for closure and a new beginning. Given the unique nature of the AfricanAmerican travel experience to Africa, it is important to place the discussion within the relevant historical context of the Black Diaspora.

\section{The Black Diaspora and Tourism}

It is an established fact that there were two distinct regional slave trading traffic routes from Africa for several centuries prior to the first significant European contacts with Africa in the 14th century. For example, the Trans-Sahara slave trade was from Western and Central Africa to North Africa, while the Red Sea slave trade exported slaves from Eastern Africa to Arabia and South Asia. Africa's contact with Europe established the third area of slave traffic that consisted of the TransAtlantic slave trade from West Africa to mostly the Americas, but also Europe. This was by far the most dominant region in terms of the number of slaves captured, trafficked, and sold, the duration of the slave raids, trading, and slavery, as well as the impact on both sides of the Atlantic Ocean. The slave "trade" activities covered extensive geographical areas in Africa, the Americas, and Europe, involving enormous distances, and millions of lives that were lost in order to secure enormous profits. Figures are hard to establish, but some scholars suggest that while the Trans-Sahara and Red Sea trade involved about 6 million slaves, in the Trans-Atlantic slave trade "from the 1520 s to the $1860 \mathrm{~s}$, an estimated 11 to 12 million African men, women, and children were forcibly herded onto European vessels for a life of slavery in the Western Hemisphere" (Appiah \& Gates, 1999, n.p.). Over a period of about 350 years, an estimated 9-10 million African slaves survived the TransAtlantic voyage as human cargo to be purchased by White plantation owners and slave traders in 
the New World of the Caribbean, Latin America, and North America.

While African slaves were sold in slave markets as far north as New England and as far south as present-day Argentina, today's descendants are spread all over the world. It is this global dispersal of peoples of African heritage that has come to be known as the Black Diaspora. With the exception of a few freed slaves that were returned to Sierra Leone and Liberia in West Africa by England and the US, respectively, following the abolition of slavery, the vast majority of today's descendants of African slaves are concentrated in the geographical regions of the Caribbean, North, Central, and South America, as well as in a few European countries such as the UK and France.

The dispersal of a large and diverse number of ethnic groups around the world for various reasons has been a major factor in international tourism development, with Europe, a prime example. It continues to be the leading international tourist region, accounting for $54.4 \%$ of the estimated 846 million international tourist arrivals and $51.1 \%$ of the estimated $\$ 733$ billion tourist receipts in 2006 (United Nations World Tourism Organization [UNWTO], 2007). This dominance can be attributed to the region's diverse array of cultural and historical resources and attractions, Europe's global colonial influence between the 15th and early 20th century, and to the global dispersal of European peoples and cultures. Today, this constitutes a significant foundation for the promotion of ethnic tourism to Europe with pilgrimage tourism being a major component. For example, the great wave of emigration between 1901 and 1910 brought 9 million immigrants to the US, mostly from Europe. Their children are among the 79 million born between 1943 and 1960 referred to as Baby Boomers, whose 93 million births were between 1970 and 1977. Together, the three groups contribute to make the US the single most important market for European international tourism. Leading European destinations for American visitors are principally the ancestral homes of American immigrants who left Europe beginning in the late 1800 s and early 1900s. A consequence of the different waves of interregional global migration is today's numerous examples of travel flows between regions and countries for ethnic reasons, such as between Europe and the US, between Israel and the US or Europe, between the UK and Australia or New Zealand, and between Spain and Latin America.

African-Americans constitute a tremendous ethnic market for Africa's tourism industry for a number of reasons. First, with a population of 34 million, they are the single largest group of African descent in any country. Second, their average income level has experienced annual growth rate of about $16 \%$ between 1990 and 2006, currently representing a $\$ 400$ billion market. As a result, about 12 years ago, the African-American market was considered to be the 14th largest market with more disposable and discretionary income than Australia, Mexico, or Russia (USA Today, 1998). Third, African-Americans predominantly constitute a single linguistic market. Unlike peoples of African descent in many countries in the Caribbean and Latin America who speak various languages, including English, French, Spanish, Portuguese, and various derivations of local and European languages such Patios, Creole, and Papiamento, the primary language of African-Americans is English. This factor tends to facilitate and enhance their travel experiences in Africa, including travel to the large number of Francophone countries in West Africa. All the major Frenchspeaking countries in Sub-Saharan Africa share, at least, one common border with an English-speaking country. Fourth, the growth and significance of the African-American market for both domestic and international travel has been recognized by key sectors of the travel industry including hotels, airlines, cruise lines, and theme parks. For example, in 1993 the Travel Industry Association of America (TIA) commissioned what it called its first-ever benchmark study on the demographic and economic characteristics, and travel patterns and attitudes of African-Americans (TIA, 1993). Finally, the economically prosperous AfricanAmerican population tends to be concentrated in large metropolitan areas, which are also gateways for international travel. For example, AfricanAmericans living in the five cities of New York, Chicago, Los Angeles, Philadelphia, and Washington, DC constitute about $27 \%$ of the total US population. Other cities with significant AfricanAmerican populations include Atlanta, Miami, and 
San Francisco. Through the general print and electronic media, but in particular, Black radio, television, and magazines, the travel industry is able to reach this huge market. The foregoing factors provide tremendous opportunities for African countries to individually or collectively direct their marketing efforts toward the African-American market. It is in this broad context that the article now proceeds to briefly examine aspects of recent tourism development in Ghana and the Central Region of the country.

\section{Potential for Cultural and Heritage Tourism Development}

"Heritage," as used in this study, refers to both tangible (physical) and intangible items of value from a society's past creation and inheritance that have been passed on to the present generation. Key resources that may be incorporated into tourism have been classified elsewhere (Prentice, 1993), but may include historical sites or buildings (forts and castles, religious shrines), or cultural heritage (festivals, arts and crafts). With regard to tourism, if properly developed, managed, presented, and interpreted, heritage attractions can offer great economic and cultural benefits for host destinations, in addition to visitors deriving cultural, personal, emotional, spiritual, and educational benefits. Ghana possesses significant cultural tourism resources that have been identified in the 15-Year National Tourism Development Plan to include a variety of "significant historic places," archaeological sites, a large number of festivals, vibrant hi-life music and dance, colorful markets, authentic arts and crafts, and a genuinely friendly and hospitable population (Ministry of Tourism/WTO/UNDP, 1996). The single most important category of cultural resources with a major potential for heritage tourism development in Ghana are the numerous forts and castles built along the coast between the 15th and 18th centuries by various European countries, including the Portuguese, Dutch, Danes, Germans, Swedes, and English. They served different functions such as trade, commerce, administrative rule, and military activities that also have significant relevance for contemporary development; however, these forts and castles were particularly notorious for the role they played in the Trans-Atlantic slave trade. Africans, captured along the coast or in the interior and taken to the coast, were imprisoned in some of these fortifications for several weeks or months, and then transported overseas, mostly to the Americas (Ministry of Tourism/WTO/UNDP, 1996). The concentration of about 50 European forts and castles along Ghana's 350 miles of coastline, several of which are still relatively well preserved (van Dantzig, 1999), is significant for three main reasons. First, it makes Ghana unique compared with any other African country with respect to the number of such historical and cultural structures built by different European countries. Second, it is an indication of the intensity of European activities in the part of Africa known as the Gold Coast. Third, the number of these forts and their role in the slave trade probably point to a more than proportionate number of the ancestors of today's African-Americans with their origins from this part of West Africa. These historical structures constitute a critical component of a relatively new but major cultural tourism project of international significance initiated in the early 1990s. It would have tremendous tourism potential for Africa and the rest of the world, but in particular, for Ghana, the forts and castles, and Africans in the Diaspora.

At a joint meeting of the UNWTO and the United Nations Educational Scientific and Cultural Organization (UNESCO) held in Accra (Ghana) in April 1995, the decision was formalized "to rehabilitate, restore, and promote the tangible and intangible heritage handed down by the slave trade for the purpose of cultural tourism, thereby throwing into relief the common nature of the slave trade in terms of Africa, Europe, the Americas, and the Caribbean" (WTO/UNESCO, 1995). This resolution was formally adopted at the 27th meeting of the UNWTO Regional Commission for Africa in 1995 in Durban, South Africa. This program, which has become known as the Slave Route Project, is directly linked to cultural tourism development, within the context of the preservation and restoration of world sites and corridors:

In the final analysis, the program aims to forge a close link between the ethical exigencies of pre- 
serving the memory of the slave trade, which historians now consider "the biggest single tragedy in the history of man on account of its scope ...." The forts and castles on the coast of Ghana, in particular, Cape Coast, Elmina, and l'Ile de Goree on the Senegalese coast, symbolize these memorial sites. And now that they have been placed on the list of UNESCO's world heritage, their preservation, restoration, and promotion henceforth forms part of the universal heritage of mankind. It is also the case of other sites like Ouidah (Benin), Angola, Mozambique, Tanzania, etc. (UNWTO/UNESCO, 1995)

\section{The Study Area}

Located about $10 \mathrm{~km}$ apart, Cape Coast, the regional capital, and Elmina, are the primary community centers of the Central Region. The tourism resources of this region are varied, but the prominent attractions include three World Heritage forts and castles located in these two towns, which have been rehabilitated to serve as various cultural tourism attractions. Located north of Cape Coast and Elmina is a slave market site at Assin Fosu that links the slave route from the interior of the country through the former powerful Ashanti Kingdom based in Kumasi with the slave forts and castles on the coast. Within a $25-\mathrm{km}$ radius of Cape Coast and Elmina are the newly developed Kakum National Parks and a multiple land-use beach resort development project at Brenu-Akyenin. Ostensibly, tourism is being developed in the region as a lead sector by the national government with assistance from such international organizations as the United Nations Development Program (UNDP) and the United States Agency for International Development (USAID). While the existence of tourism resources has enabled the planning and development of tourism in the region (Ministry of Tourism/UNDP/WTO, 1996), the objective is to reverse the decline in the regional economy "after losing its role in the colonial spatial organization and the subsequent post-independence restructuring of national transportation systems" in the late 1800s (Akyeampong, 1996). Specifically, Cape Coast served until 1877 as the capital and seat of the governor of the British colony of the Gold Coast that later become Ghana after its 1957 independence. The loss of political and administrative status started the decline of the whole region, which continued throughout the rest of the British colonial period. The town continued to hold on to its economic reputation as a national surf port and major trading center until 1962 when a new modern port was built at Tema near the capital city, Accra. Similarly, Elmina was the first community in the Gold Coast to come into contact with Europeans in 1471 when the Portuguese landed to pursue the lucrative gold trade. They built the San Jorge da Mina (St. George the Mine) Castle, which, together with the Cape Coast Castle built later by the Swedes in 1653, played a significant role in the Trans-Atlantic Slave Trade. The end of the gold and slave trades brought reversals in Elmina's economic fortunes. The contemporary socioeconomic conditions of Cape Coast, Elmina and, indeed, the Central Region of Ghana as they relate to the present study is succinctly stated by Akyeampong (1996) as follows:

The Central Region is therefore the typical excolonial, sub-national region with an economic history and spatio-economic structures very similar to other Sub-Saharan coastal regions. As other nations embark on tourism promotion for local or regional development purposes they should have a great deal to learn from the Central Region's approaches and experience (p. 7).

While the histories of the two communities are linked together, there are a number of structural differences. As the capital of the Central Region, Cape Coast has a more diversified economy based on government services, a leading center of tertiary education in Ghana, consisting of more than a dozen secondary boarding schools and a major university. It is also a main highway transportation hub and a center of regional trade and commerce. Consequently, its population is larger and consists of more educated professionals with relatively higher incomes. Elmina, on the other hand, has a narrower economy based mainly on fishing. However, because two of the three main forts and castles are located in Elmina, both destinations, given their close proximity, are jointly marketed as one destination and end up on the itinerary of both African-American and White tourists visiting the Central Region. 


\section{Methodology}

Data for this study were gathered in Cape Coast and Elmina using the interview method to administer survey questionnaires that contained a 20item scale to measure how residents feel about White tourists and African-American visitors to Elmina and Cape Coast. The questionnaire contained an additional 85 items that measured various aspects of residents' attitudes toward tourism development. In order to obtain a representative sample for this study, 250 residents from each community were surveyed. The final study sample consisted of 215 and 249 residents in Elmina and in Cape Coast, respectively. This determination was based the common methodology for social science research in the two towns by the departments of sociology, political science, and geography, as well as the Consultancy Unit, all at the University of Cape Coast. A critical consideration in determining the sample size was the composition of households units. Most household units in the study area consist of a few to several extended family members who, in turn, constitute separate individual family units occupying a family home inherited from common grandparents or even great grandparents. The sample size for this study was based on the nucleus family household that may be free standing of part of a larger extended family household. Representatives of households were interviewed and, whenever necessary, research assistants speaking the Fanti language interpreted the survey to the respondents. The overall response rate was high: $86 \%$ for Elmina and $99.6 \%$ for Cape Coast. Missing data were replaced using a regression imputation technique similar to that used by Sirakaya (1997). This approach requires a brief clarification. Using imputation techniques for a small proportion of the data does not result in data distortion if incomplete observations contain a large number of variables with complete values. Because the data set of this study contained less than $3 \%$ of observations with missing data for some items, it was decided to replace the missing data points by using a regression imputation technique, which is usually preferred over the mean substitution technique. Evidently, independent variables were not imputed, as this would have biased the resulting statistics (Little \& Rubin, 1987).

\section{Results}

With regard to selected sociodemographic characteristics of respondents shown in Tables 1 and 2 , the majority $(62.7 \%)$ of respondents was male (37.3\% female). With respect to the number of years lived in the same community, the mean was 16.8 years, while the mean educational level of the residents was 12.10 years. The mean age of the respondents was 34.3 with a standard deviation of 10.15 . Only $9.0 \%$ of the residents were employed directly by the tourism or its related industries and only $17.3 \%$ had at least one family member employed by the tourism industry. This is an indication of the current low level of tourism activity in both communities. An interesting attribute of respondents is the average number of days per week of interaction with tourists. These were 2.32 and 3.02 in Cape Coast and Elmina, respectively, and would appear to be high for such communities with relatively low levels of tourism activity.

A varimax rotated principal component analysis was used on 20 items for a sample of 464 residents to extract general groups of residents' perceptions of tourists from two ethnically different groups of tourists (White and African-American) visiting the two towns of Elmina and Cape Coast. The Kaiser-Meyer-Olkin (KMO) statistics of 0.887 and inspection of correlation among the items indicated that the data were suitable for a factor analysis (Norusis, 1994). A cut-off point of 0.4 was used to include items in interpretation of a factor. Nine of the initial 20 items did not load on any factor, loaded on two factors simultaneously, or had low loadings, making the interpretation of

Table 1

Residents' Profiles

\begin{tabular}{lr}
\hline & Frequency (\%) \\
\hline Gender & \\
$\quad$ Female & $171(37.3)$ \\
$\quad$ Male & $287(62.7)$ \\
Employed by the tourism or related & \\
industries & \\
$\quad$ Yes & $41(9.0)$ \\
$\quad$ No & $417(91.0)$ \\
Family member employed in tourism or & \\
related industries & \\
$\quad$ Yes & $79(17.3)$ \\
$\quad$ No & $378(82.7)$ \\
\hline
\end{tabular}


Table 2

Respondents' Age, Residency, and Education

\begin{tabular}{lccc}
\hline & Minimum & Maximum & Mean (SD) \\
\hline Age of the respondents & 17.0 & 76.0 & $34.27(10.159)$ \\
Length of residency & 1.0 & 53.0 & $16.78(11.167)$ \\
Education level & 0.0 & 25.0 & $12.11(4.709)$ \\
\hline
\end{tabular}

the factors difficult. Accordingly, factor loadings were inspected and improved by progressively deleting individual items from further analysis until clean factor solutions were obtained. After several runs, the analysis yielded two distinct factors for each of the tourist group with Eigenvalues equal to or greater than 1, explaining $53 \%$ of the variance in the original data set. Interestingly, a review of the factor loadings suggests that responses to items measuring perceptions of both groups of tourists tended to load consistently on the same domain. Thus, it was decided that two conceptually consistent factor solutions would be used in the analyses. The two factors were labeled: 1) General Perceptions of Tourists (Factor 1), and 2) Perceptions of Social and Economic Condition of Tourists (Factor 2). The two conceptually meaningful domains from the results of factor analysis were then tested for reliability, using Cronbach's alpha coefficients, which were moderate 0.74 (domain 1 for Black tourists) to a low 0.64, (domain 2 for White tourists). To arrive at a general score for the items, each factor mean score was calculated by adding the raw mean score of each individual item. In the subsequent statistical analyses, these factor means were used to test the study hypotheses. Table 3 displays the items along with their factor loadings, Eigenvalues, percentage of variance explained, and corresponding alpha reliability coefficients. "Black tourists" as used throughout this study, refers specifically to "African-Americans" or "Black Americans." This is the wording used in the survey and reflects the fact that Ghanaians use these descriptors interchangeably.

Tables 4 and 5, on the other hand, contain the names of the factors along with descriptions and operationalizations of other variables used to test the hypotheses. (For the remainder of the article, the abbreviations will be used when discussing the variables in question.) To obtain reliable statistics, variables containing categories such as "income" and "employment status" were screened for cell numbers. It was determined that "employment status" should be collapsed into only three categories containing "employed," "unemployed," and "others" (students, retired).

Because the purpose of the study was to compare residents' perceptions of two ethnically different groups of tourists, for each pair of factors, $t$-tests were performed. In addition to the $t$-tests, ANOVA and Pearson's product moment correlation procedures were used to test the main hypotheses of the study. Table 6 displays the hypotheses tested, statistical tests performed, and the summary of test results.

The first hypothesis (H1) was rejected as $t$-test results indicated that there were statistically significant differences between two pairs of factor scores presented in Table 7. For Factor 1, residents' perceptions of Black tourists were on the whole more positive than their perceptions of White tourists $(t=5.40, p<0.000)$. For Factor 2 containing items describing the social and economic status of tourists, the difference appeared to favor White tourists. White tourists were perceived by residents in a more positive light than Black tourists $(t=-8.59, p<0.000)$. However, from the results in Table 7, an examination of the overall mean scores for tourist groups regarding Factor $2\left(\right.$ mean $_{\text {White }}=1.8063$, mean $_{\text {Black }}=2.0232$, respectively) suggests that tourists visiting Cape Coast and Elmina were perceived by residents as being poor, dirty, ordinary, and unfriendly. Black tourists in this regard were regarded more negatively than their White counterparts.

When evaluating residents' perceptions of Black and White tourists in their two communities, there was a significant town-effect on residents' attitudes. The second hypothesis (H2) was 
Table 3

Summary of the Factor Loadings Following Varimax Rotation of Two Independent Samples

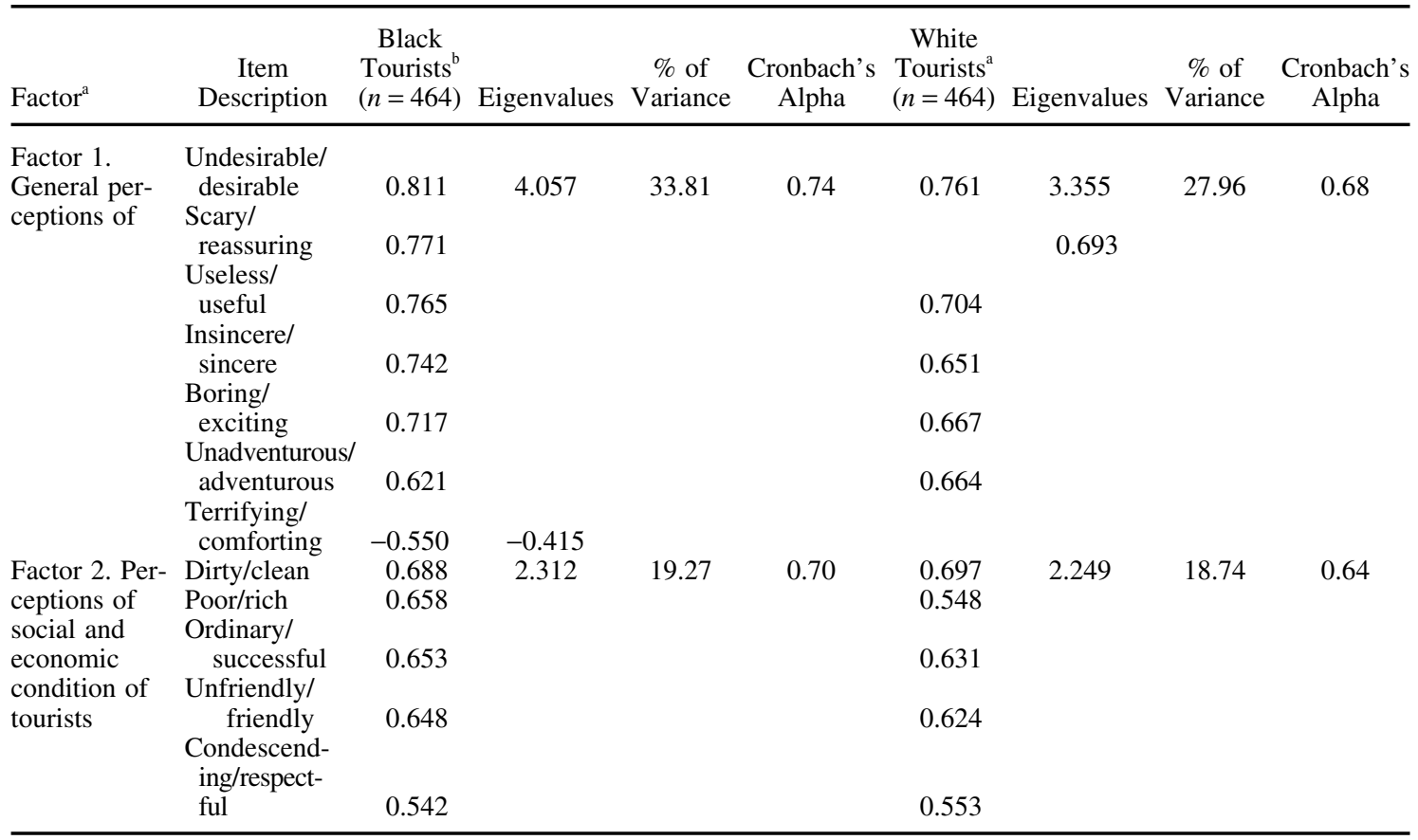

Kaiser-Meyer-Olkin Measure of Sampling Adequacy $=0.887$.

${ }^{a}$ Total variance explained by pooled data $=46.96 \%$.

${ }^{\mathrm{b}}$ Total variance explained by pooled data $=53.07 \%$.

rejected because the $t$-test results indicated statistically significant differences between the scores for the two towns for BLACK 1. Specifically, residents of Elmina, in general, had more positive perceptions of Black tourists (mean $=3.66, \mathrm{SD}=0.581$ ) than residents of Cape Coast for the same group (mean $=3.55, \mathrm{SD}=0.521)$.

The mean scores of residents' perceptions regarding the two factors for Black and White tour-

Table 4

Dependent Variables

Code Description of Dependent Variables

BLACK 1 General perceptions of Black tourists (Factor 1)

BLACK 2 Perceptions of social and economic condition of Black tourists (Factor 2)

WHITE 1 General perceptions of White tourists (Factor 1)

WHITE 2 Perceptions of social and economic condition of White tourists (Factor 2) ists did not differ significantly from each other for EMPSTATUS, TEMPLOYED, and FAMEMPLOYED. These results are presented in Table 8. Consequently, we failed to reject the initial null hypotheses regarding these variables $(\mathrm{H} 3, \mathrm{H} 4, \mathrm{H} 5$ were accepted).

To test the seventh hypothesis (H7), an ANOVA was performed, for which the results are displayed in Table 9. No income effect was found on residents' perceptions of tourists; hence, the null hypothesis 7 (H7) was accepted.

To test the remaining hypotheses, bivariate correlation analyses were performed. Table 10 shows the Pearson's product moment correlations between residents' perceptions and the remaining variables. Further examination of results in this table indicates that EDUCATION and BENEFITS had a significant positive relationship with perception factors at the 0.01 significance level. Specifically, as EDUCATION of residents increased so did the WHITE 2 and BLACK 2 scores; hence, 
Table 5

Independent Variables

\begin{tabular}{lll}
\hline Code & \multicolumn{1}{c}{ Description of Independent Variables } & \multicolumn{1}{c}{ Measurement Level } \\
\hline INTERACT & Number of days interacted with tourists per week & Ratio \\
BENEFITS & Perception of personal benefits gained from tourism activity & Interval (5-point Likert scale) \\
TEMPLOYED & Employed in tourism or related industry & Nominal (dummy coded: yes or no) \\
FAMEMPLOYED & Member of family employed in tourism or related industry & Nominal (dummy coded: yes or no) \\
PRJAWARE & Awareness of tourism projects in the community & Interval (5-point Likert scale) \\
SEX & Gender & Nominal (dummy coded: male or female) \\
AGE & Age of respondents & Ratio \\
EMPSTATUS & Employment status (employed unemployed or others) & Nominal (dummy coded: yes or no) \\
EDUCATION & Education level & Ratio \\
RESIDENT & Length of residency & Ratio \\
\hline
\end{tabular}

we rejected our null hypotheses $\mathrm{H} 8$ and $\mathrm{H} 9$. It seems that perceptions about tourists' socioeconomic status is positively related to education levels of the residents; the more educated the residents were the more positively they viewed the tourists' socioeconomic status. BENEFITS, on the other hand, had a positive relationship with WHITE 1 and BLACK 1, leading to the rejection of the hypothesis 9 (H9). As residents felt that they personally benefit from tourism, their perception scores for WHITE 1 and WHITE 2 factors increased significantly. All other variables tested had no relationship with the factors hence the null hypotheses $\mathrm{H} 10, \mathrm{H} 11$, and $\mathrm{H} 12$ were accepted at the 0.05 significance level.

\section{Discussion and Conclusion}

The findings of this study indicate that residents of the two communities in Ghana have a number of interesting and somewhat conflicting perceptions of Black and White international visitors. First, with respect to the general perception of visitors (Factor 1), results indicate that residents have a more positive view of Black tourists compared with White tourists. However, regarding the social and economic status of visitors (Factor 2), residents perceived White tourists more favorably than Black tourists. A possible explanation for this difference may lie in the fact that in broad cultural terms, Ghanaians certainly identify more with African-Americans, but may hold Whites in higher regard with respect to their social and economic status. Second, the results of the study show that, on the whole, residents perceived both White and Black visitors as being poor, dirty, ordinary, and unfriendly. Interestingly, Black tourists were viewed more negatively than their White counterparts. A more specific interpretation of these findings is that while Ghanaians identify more with African-Americans, and view White visitors in a higher socioeconomic regard, the category of both races currently being attracted to Cape Coast and Elmina are perceived negatively, with respect to their socioeconomic status. Placed within the context of the theory of the destination life cycle and the types of visitors attracted at various stages of destination development (Plog, 1974), it can be argued that Cape Coast and Elmina are at the inception stage and correspondingly, are attracting adventurous and budget travelers, a point made in the introduction of this article. It is also important to note that as a result of such annual special cultural events such as the Pan-African Festival of Arts (PANAFEST) and Emancipation, Ghana attracts an increasing number of visitors from some Caribbean Islands, especially Jamaica. It is possible that some residents of Cape Coast and Elmina misidentify some of these visitors as AfricanAmericans, especially if the residents do not have the opportunity for interaction with these visitors. Another possible explanation may lie in the nature of the organized inclusive tours to Cape Coast and 
Elmina. Most tourists arrive in Cape Coast and Elmina on organized tours operated by companies based in Accra (about a 2-hour drive) for the day and return or continue on to other regions. It is most likely that the references to "poor, dirty, ordinary, and unfriendly" pertain to the independent (FIT) market segments of both Black and White tourists.

Third, the results of this study support some of the findings in an earlier study, also in Cape Coast and Elmina, by Bruner (1996) that: Ghanaians generally welcome tourists but, in the focus groups, some tourists were considered "ruffians," "dirty," and "drug addicts," and some of their behavior were considered "shocking." A 46-year old female (resident) said some tourists are "really dirty," and some "look like madmen." A 44-year old male (resident) said, "The way some of them dress, the way some of them have their earlobes pierced, the very short dresses of the women which exposes their private parts, is what I don't like about them." A 19-year old female (resident) said, "Some are Rastafarians and I think they do not normally bathe. We don't like that."

Fourth, the study indicates significant differences in the perceptions of residents in the two communities. Residents of Elmina perceived Black visitors more positively than residents of Cape Coast. The difference may be due to the fact that Elmina, with its two forts and narrow economic

Table 6

Hypotheses of the Study

Hypotheses Tested

Statistics Used

Results

H1: There is no statistically significant difference of residents' mean percep- $t$-test

reject

tion scores between Black and White tourists

$\mathrm{H} 2$ : There is no statistically significant difference of residents' mean percep- $t$-test

reject

tion scores of Black and White tourists between two Ghanaian towns

H3: There is no statistically significant differences between employed and unemployed/other residents' mean perception scores of Black and White tourists

H4: There is no statistically significant differences between mean perception scores of residents who are employees of tourism/related industries and residents who are not employees of tourism sector

H5: There is no statistically significant differences between mean perception scores of residents whose families are employed by the tourism sector/related industries and residents whose families are not employed by the tourism sector

H6: There is no statistically significant difference between male and female residents' perception scores of Black and White tourists

H7: There is no statistically significant differences in residents' mean perception scores among the three income groups (less than 600,000 Cedis; 600,000-999,999 Cedis; above 1,000,000 Cedis)

H8: There is no correlation between residents' mean perception scores of Black and White tourists and the education levels of residents

H9: There is no correlation between residents' mean perception scores of Black and White tourists and the extent of personal benefits gained from tourism

H10: There is no correlation between residents' mean perception scores of Black and White tourists and number of days interacted with tourists per week

H11: There is no correlation between residents' mean perception scores of Black and White tourists and their age

$t$-test

accept

$t$-test

accept

$t$-test

accept

H12: There is no correlation between residents' mean perception scores of Black and White tourists and the length of residency in the community

(1)

$t$-test

ANOVA

reject

accept

Pearson's product moment correlation reject

Pearson's product moment correlation

reject

Pearson's product moment correlation accept Pearson's product moment correlation accept 
Table 7

$i$-Test Results of Factors in Pooled Sample Comparing Perceptions of Black and White Tourists

\begin{tabular}{lcccc}
\hline Pairs & Factors & Mean (SD) & $t$ & Sig. (Two-Tailed) \\
\hline Pair 1 & Factor 1-Black & $3.66(0.581)$ & 5.40 & 0.000 \\
& Factor 1-White & $3.55(0.521)$ & & \\
Pair 2 & Factor 1-Black & $1.81(0.548)$ & -8.59 & 0.000 \\
& Factor 1-White & $2.02(0.562)$ & & \\
\hline
\end{tabular}

base, depends more on the tourist business. Cape Coast, on the other hand, has a broader economic base that includes public sector services, several high schools, a university, and a viable retail sector. Hence, it may be relatively more critical of the socioeconomic status of Black visitors than residents of Elmina. A fifth finding of the study relates to possible gender differences in residents' perceptions of visitors. On the whole, female residents perceived visitors more negatively than male residents. It has been noted that "Locals are offended when tourists walk through the town in swimming suits, bikinis, or when they wear seethrough clothing" (Bruner, 1996, p. 300). Furthermore, this study found significant relationship between residents' educational level and their perceptions of both Black and White visitors. It appears that as educational levels increase, perceptions of visitors' socioeconomic status become more positive. Finally, an important finding from the study pertains to the extent of involvement and benefits derived from the tourism industry. Residents who felt that they personally derive benefits from the tourism industry, perceived both Black and White tourists more positively. This finding has important implications, for it appears that as tourism expands to increase direct and indirect community participation and benefits, more residents may have more favorable perceptions of visitors to their community.

As a preliminary study of residents' perceptions of the two main cultural groups of visitors to Ghana, the findings focus on a small area that deals with one aspect of hosts' perceptions of guests. There are, however, several equally important and interrelated issues that need to be explored. For example: What are the expectations of African-Americans when visiting Africa? What are their experiences when they visit the slave forts and other heritage sites? How do these experiences compare with those of White visitors? What is the group dynamics between White and Black tour groups visiting these heritage sites? How do African-Americans perceive their Ghanaian hosts? Other issues that relate to visitors' activities such as taking photographs of local, residents' lack of awareness and involvement in the development of their cultural heritage, as well as

\section{Table 8}

Independent Samples $t$-Test for Equality of Means

\begin{tabular}{lcccccccc}
\hline & $\begin{array}{c}\text { BLACK 1 } \\
\text { t-Value }\end{array}$ & $\begin{array}{c}\text { Sig. } \\
\text { (Two-Tailed) }\end{array}$ & $\begin{array}{c}\text { BLACK 2 } \\
t \text {-Value }\end{array}$ & $\begin{array}{c}\text { Sig. } \\
\text { (Two-Tailed) }\end{array}$ & $\begin{array}{c}\text { WHITE 1 } \\
t \text {-Value }\end{array}$ & $\begin{array}{c}\text { Sig. } \\
\text { (Two-Tailed) }\end{array}$ & $\begin{array}{c}\text { WHITE 2 } \\
t \text {-Value }\end{array}$ & $\begin{array}{c}\text { Sig. } \\
\text { (Two-Tailed) }\end{array}$ \\
\hline EMPSTATUS & -0.003 & 0.998 & 0.017 & 0.986 & -0.460 & 0.646 & -0.258 & 0.796 \\
TEMPLOYED & -0.617 & 0.538 & -0.292 & 0.770 & -0.870 & 0.385 & -1.379 & 0.169 \\
FAMEMPLOYED & -0.027 & 0.978 & -0.711 & 0.478 & -0.126 & 0.900 & -1.392 & 0.165 \\
CITY (Elmina vs. & & & & & & & & \\
Cape Coast) & 4.691 & $0.000^{* *}$ & -1.732 & 0.084 & 3.226 & $0.001 * *$ & 0.096 & 0.924 \\
GENDER & -2.486 & $0.013^{*}$ & 1.046 & 0.296 & -1.691 & 0.091 & -1.613 & 0.107 \\
\hline
\end{tabular}

*Significant at the 0.05 alpha level.

**Significant at the $<0.01$ alpha level. 
Table 9

ANOVA Results of Income Effect Among Income Groups

\begin{tabular}{lrrrrr}
\hline & $\begin{array}{c}\text { Sum of } \\
\text { Squares }\end{array}$ & \multicolumn{1}{c}{$d f$} & Mean Square & $F$ & Sig. \\
\hline BLACK 1 & & & & & \\
$\quad$ Between groups & 0.773 & 2 & 0.386 & 1.149 & 0.318 \\
$\quad$ Within groups & 94.142 & 280 & 0.336 & & \\
$\quad$ Total & 94.915 & 282 & & & \\
BLACK 2 & & & & & \\
$\quad$ Between groups & 1.132 & 2 & 0.566 & 1.970 & 0.141 \\
$\quad$ Within groups & 80.441 & 280 & 0.287 & & \\
$\quad$ Total & 81.573 & 282 & & & \\
WHITE 1 & & & & & \\
$\quad$ Between groups & 1.015 & 2 & 0.507 & 1.835 & 0.162 \\
$\quad$ Within groups & 77.437 & 280 & 0.277 & & \\
$\quad$ Total & 78.452 & 282 & & & \\
WHITE 2 & & & & & \\
$\quad$ Between groups & 0.805 & 2 & 0.403 & 1.194 & 0.305 \\
$\quad$ Within groups & 94.472 & 280 & 0.337 & & \\
$\quad$ Total & 95.277 & 282 & & & \\
\hline
\end{tabular}

outright prohibition to visit these sites, and Black visitors' anger at the "whitewashing" of their history and heritage through restoration activities:

For many African-Americans, the castles are sacred grounds not to be desecrated. They do not want them to be made beautiful or to be whitewashed. They want the original stench to remain in the dungeons .... a return to the slave forts for Diaspora Blacks is a "necessary act of self-realization" for the "spirits of the Diaspora are somehow tied to these historic structures." Some Diaspora Blacks feel that even though they are not Ghanaians, the castle belongs to them. (Bruner, 1996, p. 291)

Table 10

Bivariate Correlations Between Perception Factors and Selected Variables

\begin{tabular}{lcccc}
\hline & WHITE & WHITE & BLACK & BLACK \\
& 1 & 2 & 1 & 2 \\
\hline EDUCATION & 0.032 & & & $0.183^{* *}$ \\
RESIDENT & -0.007 & -0.021 & -0.050 & -0.078 \\
BENEFITS & $0.172^{* *}$ & -0.063 & $0.115^{*}$ & -0.032 \\
AGE & -0.059 & 0.076 & -0.014 & -0.021 \\
INTERACT & 0.067 & -0.018 & 0.048 & -0.026 \\
\hline
\end{tabular}

$N=453-460$ (sample size varies according to missing values).

*Correlation is significant at the 0.05 level (two-tailed).

**Correlation is significant at the 0.01 level (two-tailed).
Finally, there are issues regarding the authenticity of the presentation and interpretation of the historical events associated with these sites and structures. The restoration projects were carried out principally by foreign consultants of international agencies such as UNESCO, Conservation International (CI), and the Smithsonian Institution. Austin $(1997,2000)$ examined some of the critical issues in the development of historical and heritage structures with specific reference to Ghana's Elmina castle and concluded that for all of Africa:

How ordinary Africans as the destination hosts see and relate to the African Diaspora, in particular, and how project organizers view those undertaking the visit, whether as "tourists," "visitors," "pilgrims," or even "foreigners" is of major importance. Africans in the Diaspora on visits to the African continent see themselves as "coming home." This feeling of "coming home" and the reconnection with the land of their fathers represents the essence of their visit. In reality, most are received as strangers and treated as such by the host. (Austin, 2000, p. 213)

This study contributes to a better understanding of the key issues with respect to residents' knowledge, perceptions, and attitudes towards historical events associated with the heritage sites and properties that are being developed for tourism in vari- 
ous destinations in Africa. An interview with a long-time African-American resident in Ghana (Phillips, 2000) underscores both the enormity of the human tragedy from the Transatlantic Slave Trade and the gap between African hosts and their Black Diaspora guests:

These forts are the places where Africans were separated and the African sense was broken. If the Atlantic Ocean was to dry up there would be a double highway from the Cape to Jamaica paved with the African bones... The African doesn't really understand the slave trade. To bring it up causes him embarrassment. If they can make money out of turning these places into shrines of tourism for Africans in the Diaspora to come back and weep and wail and gnash their teeth, then so be it.... But (to) go deeper into the psychological and historical import of the slave trade is not what most Africans wish to do. (p. 121)

Heritage and ethnic tourism development through the identification and restoration of cultural resources can have tremendous economic, cultural, and environmental benefits for African countries. Like the Silk Route Project in the former Eastern European countries, the Slave Route Project is multinational in scope, but it is on a much larger scale and, above all, has necessary emotional significance for the market segment that African countries are attempting to attract as heritage visitors. This is a new development area for African countries and clear policies need to be established for a balanced development, presentation, and interpretation of the cultural resources, as well as the sensitization and education of developers, tourism operators, residents, and visitors. This study has shown that there are important differences in perceptions of visitors. In order to maximize hostguest interactions, we need to understand such issues as visitors' perceptions of residents, residents' perceptions and attitudes toward particular historical events and sites, as well as the perceptions and attitudes of the dominant visiting groups towards each other.

\section{References}

Adams, K. A. (1984). Come to Tana Toraja, "Land of the heavenly kings," travel agents as brokers in ethnicity. Annals of Tourism Research, 11(4), 469-485.
Africa Travel Association. (1999). Keynote Presentation by the Executive Director, The Africa Travel Association. Joint 33rd World Tourism Organization (WTO) Commission for Africa (CAF) Conference and the Africa Travel Association (ATA) 24th International Congress, and the Convocation of African Ministers of Tourism; Accra, Ghana May 2-7.

Akyeampong, O. A. (1996). Tourism and regional development in sub-Saharan Africa: A case study of Ghana's central region. Stockholm: University of Stockholm, Department of Human Geography.

Ap, J. (1992). Residents' perceptions on tourism impact. Annals of Tourism Research, 19(4), 665-690.

Appiah, K. A., \& Gates, Jr., H. L. (1999). Encarta Africana: Comprehensive encyclopedia of black history and culture. Microsoft Corporation.

Austin, N. K. (1997). The management of historical sites of emotional significance to the visitor: The case of the Cape Coast Castle, Ghana. Unpublished Ph.D. thesis, Strathclyde University, Glasgow.

Austin, N. K. (2000). Tourism and the transatlantic slave trade: Some issues and reflections. In P. U. C. Dieke (Ed.), The political economy of tourism development in Africa (pp. 208-216). New York: Cognizant Communications.

Belisle, F. J., \& Hoy, D. R. (1980). The perceived impact of tourism by residents. Annals of Tourism Research, 7(10), 83-101.

Brown, F., \& Jafari, J. (1990). Tourism and culture. Tourism Management, 11(1), 78-80.

Bruner, E. M. (1996). Tourism in Ghana-The representation of slavery and the return of the black Diaspora. American Anthropologist, 98, 290-304.

Canan, P., \& Hennessy, M. (1989). The growth machine, tourism, and the selling of culture. Sociological Perspectives, 32(2), 227-243.

Cohen, E. (1979). Rethinking the sociology of tourism. Annals of Tourism Research, 6(1), 18-35.

Cohen, E. (1988). Authenticity and commoditization in tourism. Annals of Tourism Research, 15(3), 371-386.

Crang, M. (1996). Magic kingdom or quixotic quest. $\underline{A n}$ nals of Tourism Research, 23(2), 415-431.

Crompton, J. L. (1979). Motivation for pleasure vacation. Annals of Tourism Research, 6(4), 408-422.

Daniel, Y. P. (1996). Tourism dance performances: Authenticity and creativity. Annals of Tourism Research, 23(4), 780-797.

Esman, M. R. (1984). Tourism as ethnic preservation: The Cajuns of Louisiana. Annals of Tourism Research, 11(3), 451-467.

Goodrich, J. N. (1985). Black American tourists: Some research findings. Journal of Travel Research, 24(2), 27-28.

Harron, S., \& Weiler, R. (1992). Ethnic tourism. In B. Weiler \& C. M. Hall (Eds.), Special interest tourism (pp. 83-92). London: Bellhaven.

Hitchcock, M. (1999). Tourism and ethnicity: Situational 
perspectives. International Journal of Tourism Research, 1(1), 17-32.

Hughes, G. (1995). The cultural constraints of sustainable tourism. Tourism Management, 16(1), 49-60.

Jamison, D. (1999). Tourism and ethnicity: The brotherhood of coconuts. Annals of Tourism Research, 26(4), 944-967.

Little, R. J., \& Rubin, D. B. (1987). Statistical analysis with missing data. New York: John Wiley.

Liu, J. C., \& Var, T. (1986). Residents' attitude toward tourism impacts in Hawaii. Annals of Tourism Research, 13(2), 193-214.

Madrigal, R. (1993). A tale of tourism in two cities. Annals of Tourism Research, 20(2), 336-353.

McIntosh, R., \& Goeldner, C. (1995). Tourism: Principles, practices, philosophies (7th ed.). New York: Wiley.

MacCannell, D. (1973). Staged authenticity: Arrangements of social space in tourism settings. American Journal of Sociology, 79(4), 589-603.

Ministry of Tourism/UNDP/WTO. (1996). Tourism development plan for the central region. Accra: Author.

Murphy, P. E. (1985). Tourism: A community approach. New York: Routledge.

Morinis, E. A. (1983). Pilgrimage and tourism. Annals of Tourism Research, 11(4), 569-570.

Moscardo, G., \& Pearce, P. L. (1999). Understanding ethnic tourists. Annals of Tourism Research, 26(2), 416434.

Norusis, M. J. (1994). SPSS advanced statistics 6.1. Chicago, IL: SPSS, Inc.

Phillips, C. (2000). The Atlantic sound. London: Faber and Faber.

Pitchford, S. R. (1995). Ethnic tourism and nationalism in Wales. Annals of Tourism Research, 22(1), 35-52.

Pizam, A. (1978). Tourism's impacts: The social costs to the destination community as perceived by its residents. Journal of Travel Research, 16(4), 8-12.

$\mathrm{Plog}$, C. S. (1974). Why destinations rise and fall in popu- larity. Cornell Hotel and Restaurant Administrative Quarterly, 14(1), 13-16.

Prentice, R. (1993). Tourism and heritage attraction. London: Routlegde.

Silver, I. (1993). Marketing authenticity in Third World countries. Annals of Tourism Research, 20(2), 302-318.

Sirakaya, E. (1997). Attitudinal compliance with ecotourism guidelines. Annals of Tourism Research, 24(4), 919-950.

Smith, V. (Ed.). (1977). Hosts and guests: The anthropology of tourism. Pennsylvania: University Press.

Smith, V. (Ed.) (1989). Host and guests: The anthropology of tourism (2nd ed.). Oxford: Basil Blackwell.

Thanopoulos, J., \&. Wall, A. H. (1988). Ethnicity and its relevance to marketing: The case of tourism. Journal of Travel Research, 26(3), 11-14.

Travel Industry Association of America. (1993). AfricanAmerican travelers: Dimensions of the African-American travel market. Washington, DC: Author.

Um, S., \& Crompton, J. L. (1987). Measuring resident's attachment levels in a host community. Journal of Travel Research, 26(1), 27-29.

United Nations World Tourism Organization. (2007). Tourism highlights 2007 edition. Madrid: Author.

USA Today. (1998). February 6.

Van Dantzig, A. (1999). Forts and castles of Ghana. Accra, Ghana: Sedco.

Van den Berghe, P. (1994). The quest for the other: Ethnic tourism in San Cristobal Mexico. Seattle, WA: University of Washington Press.

Walle, A. H. (1996). Habits of thought and cultural tourism. Annals of Tourism Research, 23(4), 874-890.

World Tourism Organization. (1999). Tourism market trends: Africa 2000: Madrid: Author.

World Tourism Organization/UNESCO. (1995). Accra Declaration on the WTO-UNESCO Cultural Tourism Program "The Slave Route." Madrid: Author. 